\title{
For a decolonial social epistemology
}

\section{Por uma epistemologia social decolonial}

\author{
Guilherme Goulart RIGHETTO' (D) 0000-0002-4208-376X \\ Cezar KARPINSKI' (iD) 0000-0003-2446-0653
}

\begin{abstract}
The visualization of Information Science as a postmodern science must aim at overcoming borderline dominant models, surpassing simplistic methodological impasses, and covering complex phenomena. In this regard, the article is inserted in the epistemological discussions, selecting social epistemology and decolonial thought as its themes. Its purpose is to identify the possible convergences between decolonial thought and social epistemology and, based on that, to propose, in an essay-like way, a decolonial social epistemology. In the methodological aspect, this is an exploratory, qualitative, and bibliographic research. The technical procedure for the analysis of the bibliography took place using a non-probabilistic approach, by judgment. The main result of this article is the construction of a historical and epistemological panorama that makes possible the approximation of thematics that, although produced in different contexts and interests, converge in a common objective: that of constituting a social, democratic epistemic field and that does not disregard the different subjects of knowledge. Thus, the reflections that combine the proposal of social epistemology with the decolonial thought or movement may bring theoretical panoramas and perspectives closer to the professional practice and research aimed at the 21 st century informational context.
\end{abstract}

Keywords: Decoloniality. Information science epistemology. Schools and philosophical currents. Social epistemology.

\section{Resumo}

A visualização da Ciência da Informação como ciência pós-moderna deve objetivar a superação limítrofe dos modelos dominantes, superando impasses metodológicos simplistas e abarcando fenômenos complexos. Nesse aspecto, o artigo se insere nas discussões epistemológicas escolhendo como tema a epistemologia social e o pensamento decolonial. O objetivo deste artigo é identificar as possíveis convergências entre o pensamento decolonial e a epistemologia social e, a partir disso, propor, de forma ensaística, uma epistemologia social decolonial. No aspecto metodológico, trata-se de pesquisa exploratória, qualitativa e bibliográfica. O procedimento técnico para as análises da bibliografia se deu mediante abordagem não probabilistica, por julgamento. O principal resultado deste artigo é a construção de um panorama histórico e epistemológico que viabiliza a aproximação de temáticas que, embora produzidas em contextos e interesses distintos, convergem em objetivo comum: constituir um campo epistêmico social, democrático e que não desconsidere os diversos sujeitos do conhecimento. Assim, as reflexões que aliam a proposta de uma epistemologia social ao pensamento ou movimento decolonial podem aproximar vertentes e perspectivas teóricas à prática profissional e a pesquisas voltadas ao contexto informacional do século XXI.

Palavras-chave: Decolonialidade. Epistemologia da ciência da informação. Escolas e correntes filosóficas. Epistemologia social.

\footnotetext{
1 Universidade Federal de Santa Catarina, Centro de Ciências da Educação, Departamento de Ciência da Informação, Campus Professor João David Ferreira Lima, Bloco B, sala 105, Trindade, 88040-900, Florianópolis, SC, Brasil. Correspondência para/Correspondence to: G. G. RIGHETTO. E-mail: $<$ rghtto@gmail.com>.
}

Received on June 5, 2020, final version resubmitted on September 21, 2020 and approved on December 4, 2020.

Como citar este artigo/How to cite this article

Righetto, G. G.; Karpinski, C. For a decolonial social epistemology. Transinformação, v. 33, e200039, 2021. https://doi.org/10.1590/2318-088920213 3e200039 


\section{Introduction}

Contemporary discussions on the field of Information Science seeking to understand its origin, scientific traits, and the possibilities of its application in the society in which we live are wide and well-known. The recognition and official record of Information Science as a scientific field dates back to the early 1960s in the United States, when a group of professors and librarians from the Georgia Institute of Technology gathered at the Conferences on Training Science Information Specialists to address issues inherent to such training locally (Brasileiro et al., 2015). Nevertheless, such an event is not enough to encompass the arising landmark of the Information Science field, since other important manifestations emerged over time in different countries, also contributing significantly to the creation of different spaces of action within this knowledge field. Such manifestations were potentiated in the context of the so-called "informational explosion" that germinated the level of scientific and technological revolutions constituted between the $16^{\text {th }}$ and $19^{\text {th }}$ centuries and extended to the second half of the $20^{\text {th }}$ century due to the consequences of the World War II (Brasileiro et al., 2015).

Hereupon, it is possible and necessary to approach the field of Information Science through the different scenarios along its trajectory, in view of the different paths it proposed to follow during its consolidation as a postmodern social science. In accordance with Wersig (1993, p.229), Information Science "[...] should not be seen as a classical discipline, but as a new prototype kind of science, driven by the need to develop strategies to solve, particularly, the issues caused by classical sciences and technologies". This view of Information Science as a postmodern science, however, must surpass the borderline dominant models of science, overcoming simplistic methodological impasses and encompassing complex phenomena. So, according to Araújo (2004), the area remains open to new dialectical and multidisciplinary bases, moving consciously into other fields of knowledge in the social sciences. Corroborating with the same author, we also point to the historical findings of Alvares and Araújo Júnior (2010), who, in their research on the historical landmarks of Information Science, show an eclectic, heterogeneous, and interdisciplinary epistemological path in the scientific constitution of the area. Thus, the epistemic construction of this scientific field focused on the object/phenomenon "information" is constant and ongoing.

Still in the Information Science epistemological field, Social Epistemology is a discipline initially viewed as related to Librarianship and assumed by Information Science within the thought of Margareth Egan and Jesse Shera. In brief, Social Epistemology is the result of the work of these two American librarians and researchers who sought a theoretical-practical epistemological field with a social and humanistic basis for Librarianship in the early 1950s (Odonne, 2007).

In this aspect, a dialogue with decolonial thought is pertinent. In summary, such a dialogue problematizes the maintenance of colonized and objective epistemologies, departing from an epistemological emancipation to combat all types of oppression and domination. The proposal is to articulate culture, politics, and economics in an interdisciplinary way in order to build an innovative field of thought that privileges the local epistemic elements to the detriment of the legacies imposed by the colonial situation (Reis; Andrade, 2018). As Quijano (1992) affirms, it is impracticable to understand the present times without mentioning what engendered their constitution: coloniality. The current colonial world is built on the "colonial companies" basis that not only subdues continents, empires, and individuals, but establishes the belief on the European historical project as the only acceptable end for all humanity. This unfolding of the colonial project is called "universalism", or "contemporary project": capitalist, neoliberal, Eurocentric, Christian, heteronormative. In accordance, Ribeiro (2014) sustains that there is a struggle to maintain a monopoly on what is considered "universal", since it constitutes one of the fundamental means for the symbolic reproduction of global elites. Once something considered universal is defined, the more a group or person fits that definition, the more "global" they are labeled. Because of the fact that so-called universals are often taken as attributes of humanity as a whole, the closer a group or person is to the universals, the more human 
they are perceived to be. In this case, idiosyncrasies are suitable for creating stereotypes and for the promotion of discrimination.

Understanding coloniality, however, gives rise to the idea that there is only a single political-economic project, only a single possible moral conformation, as well as a single way of apprehending and relating to the world - just one single possibility of existence and/or of identity. Thus, the colonial project did not just motivate the subjugation of lands, bodies, and cultures. It is an ongoing project, as it continues to promote epistemic segregations versus other worldviews (Oliveira; Osman, 2017). In this context, we defend the relevance of dialogues and studies that reflect on such circumstances within the Information Science area, mainly in the Latin American context. Therefore, the objective of this article is to identify the possible convergences between decolonial thought and social epistemology and, based on that, to propose, in an essay-like way, a decolonial social epistemology.

The relevance of the theme is centered on informational praxis, on the problem of not overcoming the colonial perspective of the area and on the search for an effective "infodiversity" (Morales, 2006), comprising respect for plurality, the rescue of the information of each locality, conservation, availability and free access to that information. The set of actions and functions that infodiversity implies allows every human being to live in an environment of plurality of ideas and thoughts, both past and present, which will provide balance in their life as an individual or as part of a social group. Likewise, infodiversity will provide them with elements in order to know the facts related to the self and to the other, to understand and fully accept diversity as a universal value, and to achieve unity in diversity. The common and the different do not destroy, but complement one another; and the diversity among individuals is a source of social energy (Morales, 2006).

This study adds up to some initiatives that have emerged in the scientific scenario of the area in Brazil. This is the case of the works of Prasad (2008) and Sánchez-Tarragó et al. (2015) that describe the movement of decoloniality or struggle against colonialism in Latin America. Also significant is the article of Silva and Karpinski (2018), that describes the result of social networks research on Nuclei of Afro-Brazilian Studies based on reflections related to post-colonial thought. In this context, the choice for Social Epistemology is justified by its proposal to be a facilitator of the social knowledge production from democratic information services. In addition, this perspective highlights the intrinsic role of Librarianship, and, by extension, of Information Science, along with the social dimension of the information treatment for the knowledge constitution in an inclusive way.

The article's main result is the construction of a historical and epistemological panorama that makes possible the approximation of themes that, although produced in different contexts and interests, converge in a common objective: constituting a social, democratic epistemic field and that does not disregard the different knowledge subjects. Thus, the reflections that combine the proposal of social epistemology with the decolonial thought or movement may bring theoretical panoramas and perspectives closer to the professional practice and research aimed at the $21^{\text {st }}$ century informational context.

\section{Methodological Procedures}

The research that resulted in this article was exploratory, qualitative, and bibliographic. Exploratory as it aimed to evolve, elucidate, and make use of various concepts and ideas, in order to formulate more precise problems or searchable hypotheses for subsequent studies. Moreover, this research type is less rigid in planning and allows investigation in different media and information sources. Sometimes, exploratory research is the first stage of a broader investigation, which is certainly applicable to the results achieved in this body of work (Santos, 1999; Flick, 2009).

Qualitative research is generally identified as concerned with studying the world "out there" (Flick, 2009, p.8), more precisely its phenomena, in a different way from quantitative research, which generally studies phenomena 
in special contexts, such as laboratories. Qualitative research analyzes experiences and examines interactions that develop in their own contexts, in a broad way, therefore not having strong control over variables as in quantitative research (Flick, 2009). In the social sciences, this type of investigation strives to a level of unquantified reality, working with the universe of meanings, reasons, wishes, beliefs, values and attitudes, whose premises cannot be reduced to the mere operationalization of variables (Minayo, 2001).

In the scope of bibliographic research, the analysis started with published documents and, in view of the exploratory and essay-like nature of the proposal, the technical procedures were directed toward a non-probabilistic approach, by judgment, being the one that the researcher uses his judgment to select the cut considered valid to the research context. (Schiffman; Kanuk, 2000). The sources of information selected in the research refer to the theoretical construction of the 'decolonial' epistemic field, to the protagonism of the epistemologies' social aspect constituted in the $20^{\text {th }}$ century, and to the centrality of Social Epistemology published by Jesse Shera in the 1970s. Based on bibliographic analyses, all these steps are developed in specific items of the article that ends with the proposal of a decolonial social epistemology for the Information Science area.

\section{Results and Discussion}

It is well known that any and all social experience produces and reproduces information and knowledge and, in doing so, presupposes one or more epistemologies. Epistemology, in turn, can be seen as the entire notion or idea, reflective or not, of the conditions of what counts as solid knowledge. It is through this knowledge that a certain social experience becomes intentional and intelligible, so there is no knowledge without social practices and individuals. These, therefore, only exist within social relations, whose distinct types of relationships can give rise to distinct epistemologies. Differences may be imperceptible and, even if the opposite is true, they may not be the subject of discussion, often being at the heart of tensions or contradictions present in social experiences, especially when, as is usually the case, they are constituted by different types of social relations (Santos; Meneses, 2009).

In the broadest sense, social relations are predominantly cultural (intracultural or intercultural) ${ }^{\mathbf{2}}$ and political (representing unequal distributions of power). So, any kind of knowledge is always contextual, in terms of cultural difference and of political difference. In addition to certain levels of cultural and political difference, social experiences are made up of various types of knowledge, each with its own validity criteria, that is, they are made up of rival and constantly conflicting knowledge (Santos et al., 2004).

The criticism imposed on a dominant epistemological regime is currently possible due to a set of circumstances that, paradoxically, assimilate better than ever the possibility and the urgency of epistemological alternatives while revealing the gigantic dimension of the political and cultural obstacles that hinder their sedimentation. The information and communication revolution, as well as its technologies, combined with capitalism's tendency to reduce the dimensions of collective life (cultural, spiritual, symbolic) and nature to the law of value - transform basic needs into commodities -, expanded the contradictions of capitalist domination and the resistance it faces at the same time that it has given them greater visibility. Therefore, the amplification of the visualization of the world's cultural and epistemological diversity has become more convincing for broader and larger audiences (Santos; Meneses, 2009).

In addition to all the dominations for which it is known, colonialism is implicated in an epistemological domination, an extremely unequal relation of knowledge-power that led to the suppression of many forms of knowledge from colonized people and/or nations. In turn, the colonial power matrix can be seen as a complex

${ }^{2}$ Unlike multiculturalism, which presupposes the existence of a dominant culture that accepts, tolerates, or recognizes the existence of other cultures in the cultural space where it dominates, interculturality presupposes reciprocal recognition and the availability for mutual enrichment between various cultures that share a given space cultural (Santos; Menezes, 2009, p.9). 
structure of interconnected levels. Accordingly, the coloniality of power is disposed by specific manners and controls, such as: the control of autonomy; the control of authority; the control of nature; the control of the expressions of gender and sexuality; the control of human matters and information/knowledge, etc. (Mignolo; Walsh, 2018).

In this sense, it is plausible to consider modern Western thought as an "abyssal thought" (Santos, 2009) arranged as a system of visible and invisible distinctions, the latter providing the basis for the former. The invisible distinctions are settled by demarcations of radical lines that separate the social reality into two distinct places: one on "the side A of the line" and the other "on the side B of the line". The division is such that "the other side of the line" disappears as a reality, becoming non-existent, and is even produced as such (Santos; Meneses, 2009). Inexistence means that it does not assume a form of being that is relevant or understandable, and is thus taken to the margins of society in a multidimensional process of social exclusion, vulnerability, and poverty - in all available ways.

Abyssal thought will continue to reproduce itself, however exclusive the practices that originate it may be, unless it is confronted by active resistance. Thus, political resistance must have epistemological resistance as its premise, building, in fact, an alternative thought of alternatives. There is a need for new thought, post-abyssal thought, a global counter-hegemonic movement, or, as Santos (2009) calls it, a "subaltern cosmopolitanism" movement, contained in networks, initiatives, organizations, and movements that fight opposite the economic, social, political, and cultural exclusion promulgated by the rise of globalization and its derived power relations.

Since societies are moved by contradictions and conflicts and considering the ability of social individuals to defy the power centered in social institutions in order to claim their own values and interests, where there is power there is also counterpower. All social systems reflect power relations and their limits, which are dealt with within a never-ending historical process of struggles and agreements. The real configuration of the State and other institutions that regulate people's lives rely on this constant synergy of power and counterpower (Castells, 2013).

Thus, post-abyssal thought assumes that the world's well-known diversity of individuals is boundless and that such diversity must also be reflected in an epistemology suitable to the social, that is, influenced by and influencing latent social complexities (Santos, 2009).

Regarding the semantic understanding of "epistemology" and "social", it is understood that epistemology can be taken as (1) synonymous with gnoseology or theory of knowledge and (2) a philosophy of science, whose meanings are interconnected, as they deal with the knowledge problem. The term "social" refers to (1) what belongs to society or has in view its structure or conditions and/or (2) analysis or study of society. However, the semantic synthesis for understanding the term Social Epistemology would occur through the relationship between the theory of knowledge and the philosophy of science, interpreted within a social context, that is, it is only possible to think about knowledge from the vantage point of a given social, historical, and temporal configuration of reality, which leads us to believe that reality is a social construction (Berger; Luckmann, 2009).

The empirical application of the term social epistemology represents two movements in scientific activity, post-positivist epistemology and the sociology of science. The first movement refers to a current in the philosophy of science that broke with the prerogatives of understanding science promoted by neo-positivists and Popperians. The second movement is the sociology of science, a branch of study within the sociology of knowledge. Its precursors were Ludwik Fleck and Robert King Merton, who developed the foundations for the advancement of Social Studies in Science (Oddone; Menezes, 2010). For a better understanding of the movements mentioned, Chart 1 presents the main characteristics of both.

Social epistemology and its genesis aim to give prominence to the synergy between human beings and their (our) constantly changing world and societies, particularly emphasizing the influence of these (inter) actions on learning processes (Oddone, 2007). This human contact with his environment, on one side, can be called ecology, in a scientific scope that considers the materiality and the collective nature of knowledge to be a socio-technical 
ecology. On the other side, the idea of Social Epistemology touched on by Egan and Shera refers to a discipline that would be the scientific foundation of Library Science, Bibliography, and Communication.

Chart 1 - Main characteristics of post-positivist epistemology and sociology of science.

\begin{tabular}{|c|c|}
\hline Post-positivist epistemology & Sociology of science \\
\hline Awareness of the human and historical-temporal character of science. & $\begin{array}{l}\text { Science is a human activity like any other, being socially and } \\
\text { historically determined. }\end{array}$ \\
\hline $\begin{array}{l}\text { Attention to the "concrete" (and not only logical-abstract) aspects of } \\
\text { scientific knowledge. }\end{array}$ & $\begin{array}{l}\text { Science, as a cultural phenomenon, must be understood in relation to } \\
\text { the contexts in which it occurs. }\end{array}$ \\
\hline $\begin{array}{l}\text { The idea that the philosophy of science, without the history of science, } \\
\text { is "empty". }\end{array}$ & $\begin{array}{l}\text { The product of science affects society to the same extent that it is } \\
\text { affected by it. }\end{array}$ \\
\hline $\begin{array}{l}\text { Tendency to root theories in broader conceptual structures, which are } \\
\text { the "paradigms" or "research programs". }\end{array}$ & $\begin{array}{l}\text { What we call scientific knowledge is a product that is socially built, } \\
\text { negotiated and applied. }\end{array}$ \\
\hline $\begin{array}{l}\text { Holistic mentality and rejection of the dichotomies between science } \\
\text { and metaphysics, context of justification and context of discovery, } \\
\text { theoretical language and observational language, etc. }\end{array}$ & $\begin{array}{l}\text { Research on science must take into account, simultaneously, its } \\
\text { institutional forms, its social uses, its practices and also its content. }\end{array}$ \\
\hline $\begin{array}{l}\text { Denial of a supposed "method" (fixed) of knowledge and any } \\
\text { "demarcation" (rigid) between science and other human activities. }\end{array}$ & $\begin{array}{l}\text { The sociology of science must be impartial, i.e., it must take as its } \\
\text { object to be explained both what is believed to be true and what is } \\
\text { believed to be false, both rational and irrational. }\end{array}$ \\
\hline $\begin{array}{l}\text { "Strong" interpretation of the theoretical character (theory ladeness) } \\
\text { and the exclusion of a neutral empirical basis capable of functioning as } \\
\text { a "verifiability" or "falsifiability" a criterion of the theories. }\end{array}$ & $\begin{array}{l}\text { The sociology of science must offer phenomena that observe } \\
\text { symmetrical explanations, i.e., to clarify both their positive and } \\
\text { negative aspects. }\end{array}$ \\
\hline $\begin{array}{l}\text { Propensity to consider theories not in terms of "truth", but in terms of } \\
\text { "consensus". }\end{array}$ & \multirow{3}{*}{$\begin{array}{l}\text { The sociology of science must be reflexive, i.e., the patterns of } \\
\text { explanation that it adopts for its objects must, identically, be applied } \\
\text { to itself. }\end{array}$} \\
\hline Tendency to insist on the "incommensurability" of paradigms. & \\
\hline $\begin{array}{l}\text { Rejection to the traditional idea of scientific progress, either in the } \\
\text { positivist way of accumulating certainties, or in the Popperian way of } \\
\text { gradually approaching the truth. }\end{array}$ & \\
\hline
\end{tabular}

Source: Adapted from Oddone and Menezes (2010).

In Shera's words, social epistemology is"a body of knowledge about one's knowledge [...] about the intellectual forces that shape social structures and institutions" (Shera, 1972, p.111), as well as a "new discipline" focused on the processes (production, flow, integration, and consumption) of all forms of thought transmitted through the entire social texture (Shera, 1973). In this logic, such a discipline would use technologies and knowledge, not only from the cognitive system of individuals, but also from the communicational network of society, with an emphasis on the following details: (1) "the problem of cognition", or how the subjects know; (2) "the problem of social cognition", including how society knows, and the nature of the psychosocial system through which inner knowledge is converted into social knowledge, that is, knowledge appropriated by society; (3) "the history and philosophy of knowledge", and how both developed over time in a variety of cultures; and (4) "the available bibliographic mechanisms and systems", and to what extent they are adapted to the realities of the communicational process, to the discoveries of epistemological research and to the substantive content of society's own knowledge stock (Shera, 1973, p.89).

Starting from the premise that, in society, social standards are always put in place aimed at ordering and coordinating individuals in their actions and roles within social structures, in addition to the exponential complexity of the flow and development of knowledge, thusly emerges the need for a social epistemology in order to investigate the intellectual processes of society, based on scientific techniques and methods (Egan; Shera, 1952). Shera (1977) asserts that the discussion about the nature of human knowledge in the past was the object of study of Philosophy and Psychology, even from the perspective of individual intellectual processes. Therefore, the difference of this 
"new discipline" would be to analyze and clarify the production of knowledge in a social dimension, seeking to understand how society internalizes and produces knowledge, without neglecting the fundamental role of the singular individual in this process.

Social epistemology would be a philosophy of the sciences that deals with the experience of knowledge that is based on the collective (and also individual) construction of social agents, taking language as an action, and permeating necessary contemporary discussions linked, for example, to the study of social networks and cultural studies of use and sharing of information (Bozzetti; Saldanha, 2017). According to Shera (1971), the study of knowledge and its informational materialization should be based on the triad of (1) atomism, i.e., the technological procedures; (2) the content, or what is transmitted; and (3) the sociocultural context, which defines the features of the two former aspects. In summary, the reflection and practice of social epistemology would be a kind of program or an epistemological, ethical, and political duty for producers, mediators, and consumers of the products of culture, knowledge, information, and communication.

Given social epistemology's importance to the present day, several scholars have dedicated their research to measuring its scope and the list of issues it raises in contemporary times. Zandonade (2004) affirms this premise by highlighting the urgency of a social epistemology in the informational ordering of social, political, and economic reality at a world level, inferring that Information Science "has already realized"that the availability of information will only be possible in the future if it is able to overcome the prevailing traditional dogmas. Fuller (1999), on the other hand, sees social epistemology as a highbrow activity that goes beyond disciplinary barriers, with the objective of reconstructing epistemological problems when considering knowledge as social from its very genesis. Social epistemology, in this understanding, encompasses a set of questions that had their first formulation related to the production of scientific knowledge, but it incorporated, over time, knowledge produced in various public and intercultural dimensions, as well as the spread of knowledge into information technology information and social appropriation.

Goldman (1999), in turn, reflects on what would be the heart of the matter for a social epistemology: whether knowledge is a property of the epistemic agent, isolated from its social environment, or whether it involves the relationships between such agents and the social conditions of the media in which they find themselves. To elucidate the issue, one must consider the type of epistemic agent, the type of knowledge, and the type of social relationships that are observed. In other words, it is essential to apprehend that the human epistemic situation is, to a large extent, shaped by social relations and institutions, a reason that fosters the field of social epistemology investigation (Goldman; Blanchard, 2015).

Based on what has been discussed so far, social epistemology continues to present contributions and reasons for its presence in Information Science, with the primary purpose of guiding analyzes on the social marks of epistemic aspects. In this sense, evaluating the premises of this perspective and of decolonial studies, we propose an approximation of the two fields, aiming at the construction of a decolonial social epistemology, which constitutes the discussion that follows.

In order to outline possible understandings and convergences of decolonial thought with social epistemology, or even a decolonial social epistemology, it is essential to identify interculturality as its "guiding thread". That is claimed since intercultural studies have first denounced the marginalization of non-hegemonic knowledge, of epistemologies that do not fit into Western scientific models, and which are part of the social scope of knowledge.

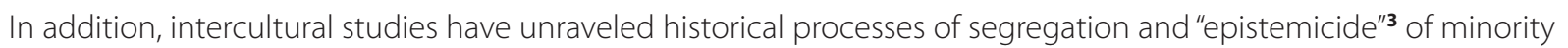
groups that are in a constant situation of social vulnerability. After all, how else to define interculturality if not as part of a process by which it is possible to integrate people from different cultures who have been socially excluded over time (also considering the multidimensionality of social exclusion), often being totally marginalized (Barboza; Lamar, 2017; Horsthemke, 2020).

\footnotetext{
${ }^{3}$ According to Santos (2002) the term "epistemicide" refers to the silencing of non-scientific epistemologies through their suppression and/or elimination. More widely, but similarly, the same expression was used by Grosfoguel (2016) to define the epistemic structure of the modern world that constituted the western epistemological privilege at the expense of the genocide of bodies and knowledge of colonial subjects in the 16th century.
} 
Reflecting on interculturality means looking at themes that relate to minority/socially vulnerable groups that throughout history have struggled for recognition, as well as talking about the power relations that segregated and annulled them. The discernment about interculturality consists in the recognition of the practices that have emerged in the last decades, trying to remove them from the exclusion and ghettos they occupy (Mignolo; Walsh, 2018). It refers to populations such as Afro-Brazilians, indigenous people, immigrants, women and Lesbian, Gay, Bisexual, Transgender, Queer, Intersex and more populations, among others who are still invisible, in the opposite side of the dominant groups in an abyssal line.

However, interculturality is not restricted to the relationship between abysmal and excluding thoughts and the division of groups and social classes/power relations, given its breadth of discussion. Interculturality goes beyond the divergences and dichotomies present in cosmopolitan societies, being necessary also in the understanding of the colonial chasms created throughout history and in the epistemological bases that support such abysmal thoughts (Barboza; Lamar, 2017). The current thought of the globalized world can be called abyssal, resuming Santos' (2007) understanding. Such thought, in a contemporary perspective, as the same author points out, "stands out for its capacity to produce and radicalize distinctions" (Santos, 2007, p.72). The term "radicalize" is justified by the fact that, in addition to producing social labels to differentiate subjects, these labels result in extreme differences, which are presented as negative and hierarchical, with one quality supplanting the other. This apprehension reinforces concepts that intercede on either side of the line, making many of their positions extreme, basing all invisible distinctions and social constructions that stipulate the limits on both sides of the line.

Having announced the problematics, subaltern cosmopolitanism emerges as an alternative element to Western modernity. It manifests itself through the so-called "counter-hegemonic globalization" (Santos, 2007) as a refuting process to the hegemonic domination of knowledge and ways of life, seeking to feed on the infinity of knowledge existing in the world and its infinite epistemes. Hence what Santos (2009) sees as the ecology of knowledge, in light of the fact that knowledge is inter-knowledge through the close relationship between knowledge forms. Associated with that,

[...] from the perspective of the global North abyssal epistemologies, policing the frontiers of relevant knowledge is far more decisive than discussions of internal differences. As a result, a massive epistemicide has been going on for the past five centuries, and an immense wealth of cognitive experiences has been wasted. To recover some of these experiences, the ecology of knowledge uses its most characteristic post-abyssal attribute, the intercultural tradition. Embedded in different Western and non-Western cultures, these experiences not only use different languages, but also different categories, different symbolic universes and aspirations for a better life (Santos, 2009, p.61, emphasis added).

As a better understanding, it is pointed out that the ecology of knowledge, as a cognitive practice, is based on the search for different experiences, not only the Eurocentric experience, which has annihilated much of the knowledge that is produced in the world, but by alternative means, such as non-science and the incorporation of different philosophical experiences that use different manifestations (Amorim, 2016).

However, criticism can be directly related to the notion sedimented by a science of "true and false", strengthened by meeting material criteria and classifying the validity or disposal of concepts, techniques, and objects. Nevertheless, if this perspective is inserted in social contexts, it will demonstrate a side of abyssal thought, as when talking about society and culture, it appears that a significant part of social groups is placed in the trenches of a "normality" imposed by social institutions that relegate the said outsiders to conditions of inferiority and, consequently, of vulnerability (Barboza; Lamar, 2017; Pillow, 2019). Consequently, any and all traces of culture that stand out from dichotomous social conventions - right/wrong, good/bad, true/false, among others -, are erased. Therefore, it is necessary to emphasize that these conventions were constituted by social agents/institutions 
inserted in the same context as the outsiders, and that the power relations they are involved in are responsible for determining the social roles and rights (or the lack of them) (Amorim, 2016).

It is also important to pay attention to the cultural values as permissible beliefs and or cultures. That is, everything that does not occur within socially pre-established parameters, for the largest side of the line is disregarded and discarded. There are countless possibilities for knowledge, values, and individuals despised by colonialist social conventions whose social dichotomies still prevail in the current century. Social, cultural, and geographical diversities are thus renounced, and the voice of the majority, read a privileged majority, constituted by those considered powerful and influential, overrides minorities (Alcoff, 2017; Barboza; Lamar, 2017). Therefore, this phenomenon can be understood as a behavior resulting from current coloniality.

Although we might have liberated ourselves from the colonial era in a historical perspective, we have inherited cultural habits that have been introjected and practiced until today. As a result, colonialist thought is inseparable from the structural and excluding violence that is now "floating" around with globalization, given that colonialist thought "[...] only conceives the system of the modern world from the point of view of its own imaginary" (Mignolo, 2010, p.34). In this respect, structural violence occurs that applies to the most diverse organized and institutionalized structures, which, in turn, lead to the oppression of groups and individuals who are denied social rights, thus making them more vulnerable to suffering and death (Boulding, 1981).

Through Santos' (2007) point of view, the fight for world justice must also be a fight for cognitive justice and, in order to be successful, it requires a new mentality, a post-abyssal thought. If, on one side, there is an abyssal thought constituted by a long separatist trajectory of classes, of socially instituted concepts and preconceptions which still insist on remaining entrenched in the social core, the other side presents a form of resistance stemming from globalization: interculturality. From this standpoint, interculturality can benefit the construction and expansion of social networks in a beneficial way, as Castells $(2013$, p.13) maintains:

Human beings create meaning by interacting with their natural and social environment, connecting their neural networks with nature's networks and with social networks. The constitution of networks is operated by the act of communication. Communication is the process of sharing meaning through the exchange of information. For society in general, the main source of the social production of meaning is the socialized communication process. This exists in the public domain, in addition to interpersonal communication. The continuous transformation of communication technology (IT) in the digital age expands the reach of the media to all areas of social life, in a network that is both global and local, generic and personalized, in an everchanging pattern. The meaning-building process is characterized by a large volume of diversity.

In view of this, the urge to develop and encourage interculturality is emphasized, not only while transiting between different cultures, but establishing social networks, exchanges and collaborations. Better said, it is a proposal that aims to go beyond just knowing what is different and admitting its existence on the other side of the line, but seeks to break the existing barriers and join the two sides in one, integrating them.

One of the great challenges of the contemporary times is to use the tools that provide contact with different cultures and social events, while resisting the colonialist barriers still present in society, which aim at the propagation of a reality already posed, in a structural way, excluding and segregating. When thinking about culture, one must go beyond values that pervade the "liking or disliking" of objects and people. The concept of culture advances on personal values, on the conceptions of the world, of existence and on the individual capacity to tolerate, accept, and understand (Ortiz, 2007; Barboza; Lamar, 2017; Mungwini et al., 2019). In Ortiz's (2007, p.10) point of view,

[...] the globalization situation is characterized by the emergence of the new and the redefinition of the "old"; both are inserted in the same context, in which different temporalities intertwine. It is therefore not necessary to oppose tradition to modernity, local to global. It is important to qualify what kind of tradition we are talking about and think about it in its forms of articulation with the modernity-world. In the same way, the local and the national should not be considered 
as disappearing dimensions; rather, it is about understanding how these levels are being redefined. In the globalization situation, a different set of social units coexists: nations, regions, traditions, civilizations. In this sense, although integrated in a global market, interconnected by communication technologies, the world is not homogeneous.

Based on the discussion, the following figure seeks to illustrate the possible convergences between decolonial thought and Shera's social epistemology that serves as a"background"for the construction of a decolonial social epistemology (Figure 1). The conception of a decolonial social epistemology, therefore, would primarily make use of such converging precepts and of the construction of an inclusive epistemic framework. In this way, the knowledge arising from the various spaces of knowledge would serve as possible "remedies" for social exclusions and vulnerabilities. This corroborates what Shera (1977, p.11) highlights as "[...] the study of intellectual life from the scrutiny of the individual for research on the means by which a society, land, or culture achieves an understanding of all the impulse that act on it".
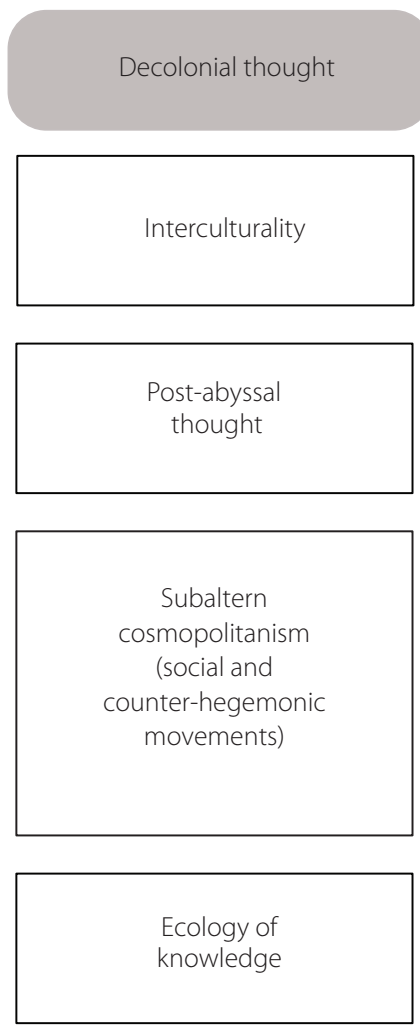

10

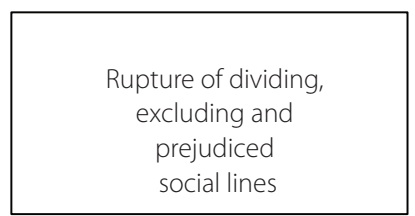

Search for plural and intercultural epistemologies
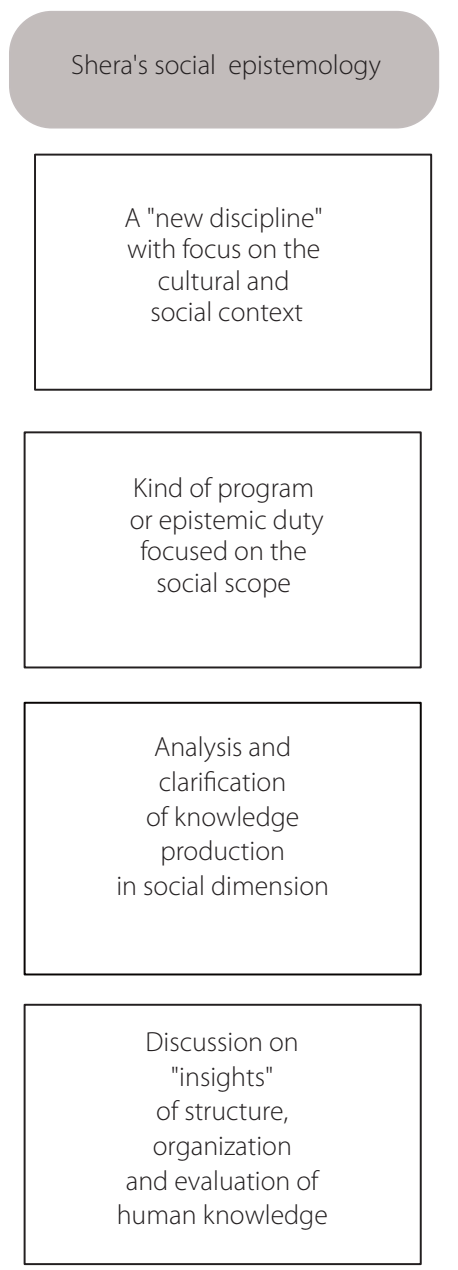

Philosophy of science that deals with knowledge in its experience, based on collective construction

\section{Decolonial social epistemology}

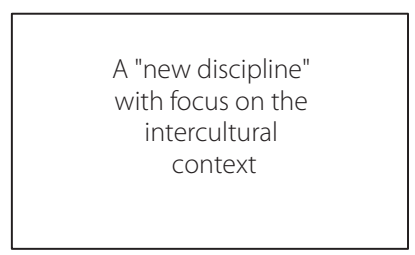

Epistemic program or duty focused on social and post-abyssal thought, subaltern cosmopolitanism and the ecology of knowledge

Discussion on "insights" of structure, organization and evaluation of human knowledge that also make possible the social/abyssal ruptures and structural violence present.

Development of plural and intercultural epistemologies dealing with collective knowledge

Figure 1 - Assumptions for a decolonial social epistemology. 
Another aspect of social epistemology that approaches decolonial thought is in the defense of a theoreticalpractical field: "[...] although social epistemology will have its very own 'corpus' of theoretical knowledge, it will also be a practice" (Shera, 1977, p.11). To a certain extent, this integrated mode of theoretical/practical knowledge would enable and promote the paradigm shift to an integrated methodological based-system, with Information Science aiming to contribute effectively to information and intercultural inclusion, empowering individuals and the social groups they are included in (Vaditya, 2018), in addition to a possible collaborative "regime" and beneficial exchange with the parties involved (Cunha, 2009).

\section{Final Considerations}

Based on the problems announced and discussed, it is understood that the principles of social epistemology published by Shera and their updating today serve (or should serve) as a driving factor in processes of production, mediation, and social appropriation of information and different types of knowledge. In addition, such principles would be appropriate for the interdisciplinary bias of a current agenda of Social and Human Sciences, among them Information Science, which demands the incorporation of studies, disciplines, and inclusive epistemic practices. In this way, the theory is seen to approach decolonial thought, interculturality and its unfolding for groups/individuals.

The resignification of the philosophical and historical conceptions of science led to the inference that, nowadays, knowledge is the result of a set of social relations established during a historical process influenced by the social environment that surrounds all human activities. Nevertheless, the role of Information Science as a postmodern social science would be justified, a priori, by its social responsibility, that is, by the social needs which it will meet without neglecting those who need it.

Decolonial thought thus becomes a transformative possibility as it regards the thoughts imposed in and to the societies in which we live. As historical-cultural individuals, it is not feasible to understand the social fabric and the reality in which we live as something set and finished. Crafting a critical-reflexive vision on what surrounds us and what we do in relation to what we see is essential. To legitimize abyssal barriers as something "natural" and "normal" is, to a certain extent, a form of subordination to socially instituted labels and of refraining from a critical and human sense of society.

The core of interculturality, paradoxically, is found in abyssal thought as the fruit of the rancorous and prejudiced thoughts of a colonial era. However, abyssal thought is still latent in the current century, with paradigms to be broken and stereotypes that segregate the valuation of different groups and social individuals. On the other hand, this same social archetype that resulted in abyssal thought sparked the construction of counter-hegemonic movements that aim to combat and resist, through interculturality, persistent inhumanities and structural violence.

Conjecturing the bases that fuse a decolonial social epistemology, therefore, can serve as a possibility of

widening and updating the ideals outlined by the precursors of Information Science and Library Science. This argument is reinforced when we refer to the individual pluralities and the abysmal inequalities of a country like Brazil, seen by reference to the "knights of the apocalypse of humanity", such as unjust inequality, racism, xenophobia, cultural denial, censorship, religious fanaticism, incitement to war, sexism, etc.

That said, it is understood, albeit initially and gradually, that the idea of breaking these dividing lines should not be through the imposition by force of the presence of the other, the strange, the different. It is necessary to integrate equally, but naturally, the two (or more) sides of the line in the middle - that is, neither in the dominant terrain of a given culture, nor in the domain of the foreigner. Rather, it is about giving in to intolerances and enabling knowledge of the new through proposals that bring visibility, protagonism and emancipation to the other (i.e., the "outsider") -, either by the continuation of this and or/by the incorporation of new studies on the themes 
addressed, or through the aggregation of infodiversity in the area of Information Science and other actions that serve as historical and cultural reparations. The urgency of a decolonial social epistemology in the rupture of preconceptions and abyssal lines as a remedy for the counter-hegemonic struggles of postmodern societies is justified again.

\section{Acknowledgements}

We thank Coordenação de Aperfeiçoamento de Pessoal de Nivel Superior (CAPES, Coordination for Higher Education Staff Development) for the social demand scholarship that enables researches such as the present one to happen, allowing the exclusive dedication of the Graduate student.

\section{Contributors}

G. G. RIGHETTO worked in data collection and analysis, and in the conception and writing of the article. C. KARPINSKI carried out the data analysis (bibliographic and conceptual review) and in the writing and revision of the article.

\section{Referências}

Alcoff, L. M. Uma epistemologia para a próxima revolução. Sociedade e Estado, v. 31, n. 1, p. 129-143, 2016. Doi: http:// dx.doi.org/10.1590/S0102-69922016000100007.

Alvares, L.; Araújo Junior, R. H. Marcos históricos da ciência da informação: breve cronologia dos pioneiros, das obras clássicas e dos eventos fundamentais. Transinformação, v. 22, n. 3, p. 195-205, 2010. Doi: https://doi.org/10.1590/S010337862010000300001.

Amorim, J. P. A. Pensamento pós-abissal e pós-colonialismo em Boaventura de Sousa Santos: críticas e avanços epistemológicos. Revista PRACS, v. 9, n. 2, p. 43-56, 2016. Doi: https://doi.org/10.18468/pracs.2016v9n2.p43-56.

Araújo, C. A. A. A ciência da informação como uma ciência social. Ciência da Informação, v. 32, n. 3, p. 21-27, 2004. Disponível em: http://revista.ibict.br/ciinf/article/view/985. Acesso em: 12 maio 2020.

Barboza, I. V.; Lamar, A. R. Interculturalidade: construção de um pensamento pós-abissal. Revista Pensamiento Actual, v. 17, n. 28, p. 46-53, 2017. Disponível em: https://dialnet.unirioja.es/ descarga/articulo/6053587.pdf. Acesso em: 22 maio 2020.

Berger, P.; Luckmann, T. A construção social da realidade: tratado de sociologia do conhecimento. Petrópolis: Editora Vozes, 2009.

Boulding, E. Las mujeres y la violencia. In: Domenach, J.-M. (org.). La violencia y sus causas. Paris: Unesco, 1981.

Bozzetti, R. P.; Saldanha, G. S. Jesse shera, the wars and the pietá: social epistemology as criticism of information ontology. Pesquisa Brasileira em Ciência da Informação e Biblioteconomia, v. 12, n. 2, p. 79-87, 2017. Available from: http://www2.marilia. unesp.br/revistas/index.php/bjis/article/view/6681/4516. Cited: Apr. 20, 2020.
Brasileiro, F. S. et al. Uma reflexão histórico-epistemológica da perspectiva social no campo da Ciência da Informação. Investigación Bibliotecológica, v. 29, n. 65, p. 137-159, 2015. Disponível em: http://www.scielo.org.mx/scielo. php? script=sci_arttext\&pid=S0187-358X2015000100007\&ln $\mathrm{g}=\mathrm{es} \& \mathrm{nrm}=\mathrm{iso}$. Acesso em: 10 abr. 2020.

Castells, M. Redes de indignação e esperança: movimentos sociais na era da internet. Rio de Janeiro: Zahar, 2013.

Cunha, M. C. Relações e dissensões entre saberes tradicionais e saber científico. In: Cunha, M. C. (ed.). Cultura com aspas e outros ensaios. São Paulo: Cosac Naify, 2009.

Egan, M. E.; Shera, J. H. Foundations of a theory of bibliography. Library Quarterly, v. 22, n. 2, p. 125-137,1952. Available from: https://www.journals.uchicago.edu/doi/ abs/10.1086/617874?mobileUi=0. Cited: May 30, 2020.

Flick, U. Introdução à pesquisa qualitativa. 3. ed. Porto Alegre: Artmed, 2009.

Fuller, S. Social epistemology. In: Bullock, A.; Trombley, S. (ed.). Norton Dictionary of Modern Thought. New York: Norton, 1999. p. 801-802.

Goldman, A. Knowledge in a social world. Oxford: Oxford University Press, 1999.

Goldman, A.; Blanchard, T. Social Epistemology. In: Zalta, N. (ed.). The Stanford Encyclopedia of Philosophy. Stanford: Centre for the Study of Language and Information, 2015.

Grosfoguel, R. A estrutura do conhecimento nas universidades ocidentalizadas: racismo/sexismo epistêmico e os quatro genocídios/epistemicídios do longo século XVI. Revista Sociedade e Estado, v. 31, n. 1, p. 25-49, 2016. Disponível em: https://periodicos.unb.br/index.php/sociedade/article/ view/6078/5454. Acesso em: 22 maio 2020. 
Horsthemke, K. The provincialization of epistemology: knowledge and education in the age of the postcolony. On education: Journal for Research and Debate, v. 3, n. 7, p. 1-5, 2020. Available from: http://edoc.ku-eichstaett.de/24085/1/ The_provincialization_of_epistemology.pdf. Cited: June 4, 2020.

Mignolo, W.; Walsh, C. E. On decoloniality: concepts, analytics, praxis. Durham: Duke University Press, 2018.

Mignolo, W. Desobediencia epistémica: retórica de la modernidad, lógica de la colonialidad y gramática de la descolonialidad. Buenos Aires: Del Signo, 2010.

Minayo, M. C. S. (org.). Pesquisa social: teoria, método e criatividade. 18. ed. Petrópolis: Vozes, 2001.

Morales, E. Diversidad, pluralidad e información: una riqueza multicultural. Documentación de las Ciencias de la Información, v. 29, p. 325-334, 2006.

Mungwini, P. et al. Why Epistemic Decolonization? Journal of World Philosophies, v. 4, n. 2, p. 70-105, 2019. Available from: https://scholarworks.iu.edu/iupjournals/index.php/jwp/ article/view/3116/237. Cited: June 4, 2020.

Oddone, N. Revisitando a "Epistemologia Social": esboço de uma ecologia sociotécnica do trabalho intelectual. Ciência da Informação, v. 36, n. 1, p. 108-123, 2007. Disponível em: http:// www.scielo.br/pdf/ci/v36n1/a08v36n1.pdf. Acesso em: 10 abr. 2020.

Oddone, N.; Menezes, V. Situando a Epistemologia Social no contexto da ciência contemporânea. In: Encontro Nacional de Pesquisa em Ciência da Informação, 11., 2010, Rio de Janeiro. Anais eletrônicos [...]. Rio de Janeiro: ANCIB, 2010. Disponível em: http://repositorios.questoesemrede. uff.br/repositorios/bitstream/handle/123456789/993/ Situando\%20-\%200ddone.pdf?sequence=1. Acesso em: 30 maio 2020.

Oliveira, M. J.; Osman, E. M. R. O. Pluralismo bioético: contribuições latino-americanas para uma bioética em perspectiva decolonial. Revista Bioética, v. 25, n. 1, p. 52-60, 2017. Doi: https://doi.org/10.1590/1983-80422017251166.

Ortiz, R. Anotações sobre o universal e a diversidade. Revista Brasileira de Educação, v. 12, n. 34, p. 7-16, 2007. Doi: https:// doi.org/10.1590/S1413-24782007000100002.

Pillow, W. S. Epistemic witnessing: theoretical responsibilities, decolonial attitude and lenticular futures. International Journal of Qualitative Studies in Education, v. 32 n. 2, p. 118-135, 2019. Available from: https://www.tandfonline.com/doi/ pdf/10.1080/09518398.2019.1576938?needAccess=true. Cited: June 4, 2020.

Prasad, A. Ciência em movimento: o que as pesquisas científicas pós-coloniais podem oferecer. Revista Eletrônica de Comunicação, Informação e Inovação em Saúde, v. 2, n. 2, p. 36-49, 2008. Disponível em: https://www.reciis.icict.fiocruz.br/ index.php/reciis/article/view/847/1489. Acesso em: 19 maio 2020.

Quijano, A. Colonialidad y modernidad-racionalidad. In: Bonillo, H. (org.). Los conquistados. Bogotá: Tercer Mundo, 1992. p. 437-49.
Reis, M. N.; Andrade, M. F. F. O pensamento decolonial: análise, desafios e perspectivas. Revista Espaço Acadêmico, v. 17, n. 202, p. 1-11, 2018. Disponível em: http://www.periodicos.uem.br/ ojs/index.php/EspacoAcademico/article/view/41070/21945. Acesso em: 10 abr. 2020.

Ribeiro, G. L. Diversidade cultural como discurso global. In: Ribeiro, G. L. (org.). Outras globalizações: cosmopolíticas pós-imperialistas. Rio de Janeiro: UERJ, 2014.

Sánchez-Tarragó, N. et al. La producción científica latinoamericana desde una mirada poscolonial. Tendências da Pesquisa Brasileira em Ciência da Informação, v. 8, n. 2, p. 182-202, 2015. Disponible en: http://eprints.rclis.org/32986/. Acceso en: 19 mayo 2020.

Santos, A. R. Metodologia científica: a construção do conhecimento. 2. ed. Rio de Janeiro: DP\&A, 1999.

Santos, B. S. Para além do pensamento Abissal: das linhas globais a uma ecologia de saberes. Novos Estudos, n. 79, p. 71-94, 2007. Disponível em: http://www.scielo.br/pdf/nec/ n79/04.pdf. Acesso em: 10 abr. 2020.

Santos, B. S. Para além do pensamento Abissal: das linhas globais a uma ecologia de saberes. In: Santos, B. S.; Meneses, M. P. (org.). Epistemologias do Sul. Coimbra: Edições Almedina, 2009. p. 23-71.

Santos, B. S. Para uma sociologia das ausências e uma sociologia das emergências. Revista Crítica de Ciências Sociais, v. 63, p. 237-280, 2002. Disponível em: http://www. boaventuradesousasantos.pt/media/pdfs/Sociologia_das_ ausencias_RCCS63.PDF. Acesso em: 12 maio 2020.

Santos, B. S.; Meneses, M.P. Epistemologias do Sul. Coimbra: Edições Almedina, 2009.

Santos, B.S. et al. Introdução: para ampliar o cânone da ciência: a diversidade epistemológica do mundo. In: Santos, B. S. (org.). Semear outras soluções: os caminhos da biodiversidade e dos conhecimentos rivais. Porto: Afrontamento, 2004. p. 23-101.

Schiffman, L. G.; Kanuk, L. L. Comportamento do consumidor. 6. ed. Rio de Janeiro: LTC, 2000.

Shera, J. H. Epistemologia social, semântica geral e biblioteconomia. Ciência da Informação, v. 6, n. 1, p. 9-12, 1977. Disponível em: https://www.brapci.inf.br/_ repositorio/2010/04/pdf_dde99ac1c9_0009749.pdf. Acesso em: 10 abr. 2020.

Shera, J. H. The foundations of education for librarianship. New York: Wiley Becker and Hayes, 1972.

Shera, J. H. The sociological relationships of information science. Journal of the American Society for Information Science, v. 22, n. 1, p. 76-80, 1971. Available from: https://asistdl. onlinelibrary.wiley.com/doi/abs/10.1002/asi.4630220204. Cited: May 30, 2020.

Shera, J. H. Toward a theory of librarianship and information science. Ciência da Informação, v. 2, n. 2, p. 87-97, 1973. Available from: https://pdfs.semanticscholar. org/2478/3bad7a03a42bc89cdbc48577e08e87737ba2.pdf. Cited: Apr. 10, 2020. 
Silva, A. S.; Karpinski, C. O contexto informacional dos núcleos de estudos afro-brasileiros: analisando o facebook como uma fonte de informação étnico-racial. Liinc em Revista, v. 14, n. 2, p. 276-294, 2018. Disponível em: http://revista.ibict.br/liinc/ article/view/4288/3951. Acesso: 19 maio 2020.

Vaditya, V. Social domination and epistemic marginalisation: towardsmethodologyoftheoppressed.SocialEpistemology,v.32,n. 4, p. 272-285, 2018. Available from: https://www.tandfonline.com/ doi/pdf/10.1080/02691728.2018.1444111? needAccess=true. Cited: June 4, 2020.
Wersig, G. Information science: the study of postmodern knowledge usage. Information Processing and Management, v. 29, n. 2, p. 229-239, 1993. Doi: https://doi.org/10.1016/03064573(93)90006-Y.

Zandonade, T. Social epistemology from Jesse Shera to Steve Fuller. Library Trends, v. 52, n. 4, p. 810-832, 2004. Available from: https://www.ideals.illinois.edu/bitstream/handle/2142/1705/ Zandonade810832.pdf? sequence $=2 \& i s$ Allowed $=y$. Cited: May $30,2020$. 